\title{
REVISION OF HUNGARIAN VERSIONS OF THE ALTERNATIVE USES AND CIRCLES CREATIVITY TESTS IN CASES OF ELEMENTARY AND SECONDARY SCHOOLS STUDENTS
}

\author{
Authors: \\ Katalin Mező (PhD.) \\ University of Debrecen, \\ Faculty of Child and Special Needs Education \\ (Hungary) \\ Ferenc Mező (PhD.) \\ University of Eszterházy Károly \\ (Hungary)
E-mail adress of the first author:
kata.mezo1@gmail.com

Lectors:

István Koncz (PhD.)

Professors for the European

Hungary Association

(Hungary)

László Tóth (PhD.)

University of Debrecen

(Hungary)

Mező K., \& Mező F. (2019): Revision of Hungarian versions of the Alternative Uses and Circles creativity tests in cases of elementary and secondary schools students. Különleges Bánásmód, 5. (1). 41-47. DOI 10.18458/KB.2019.1.41

\begin{abstract}
Although time plays a role as a latent or explicit factor in all creative processes, a direct examination of the role of time occurs less frequently in creativity research (Mező K., 2017; Mainemelis, 2002; Runco, 1999). This study focuses the revision of Hungarian versions of creativity tests because last standardization of these tests had been for more than 30 years. The applied tests were the Alternative Uses Test (as verbal creativity test), the Circles Test (as figural test) and the Raven nonverbal intelligence test (as a complementary means of study). The sample of this study was 1363 elementary and secondary school students, whose 35331 responses were recorded and analyzed. According to the results, the differences of scores of the old and new (revised) evaluation tables of all tests and age groups are significant ( $\mathrm{p} \leq 0,05)$. From viewpoint of the revised scores, there is significant difference with respect of fluency, originality and flexibility in both tests and all age groups. However, the differences of scores of other indicators (average originality, relative flexibility and revised average originality) are not significant.
\end{abstract}

Keywords: creativity, creativity tests, revision

Discipline: psychology

\begin{abstract}
Absztrakt
A SZOKATLAN HASZNÁLAT ÉS A KÖRÖK KREATIVITÁS TESZTEK MAGYAR NYELVÜ VÁLTOZATAINAK FELÜLVIZSGÁLATA ÁLTALÁNOS ÉS KÖZÉPISKOLÁS DIÁKOK ESETÉBEN

Bár az idő, mint látens vagy explicit tényező szerepet játszik minden kreatív folyamatban, az idő szerepének közvetlen vizsgálata ritkábban fordul elő a kreativitáskutatásban (Mező K., 2017; Mainemelis, 2002; Runco, 1999). Jelen tanulmány a kreativitás tesztek magyar változatainak felülvizsgálatára fókuszál, mivel ezeknek a teszteknek az utolsó sztenderdizálása több mint 30 éve volt. A vizsgálatban a Szokatlan Használat Teszt (mint verbális kreativitási teszt), a Körök teszt (mint figurális teszt) és a Raven nem verbális intelligencia teszt (mint kiegészítő vizsgálat) alkalmazására került sor. A kutatási mintát 1363 általános és középiskolás diák alkotta, akiknek 35331 válaszát rögzítettük és elemeztük. Eredményeink szerint szignifikáns különbség $(\mathrm{p} \leq 0,05)$ van a régi és az új (revideált) értékelési táblázatok pontszámai között, az összes teszt és az összes korcsoport esetében. A felülvizsgált pontszámok szempontjából szignifikáns különbség van a fluencia, az originalitás és a flexibilitás tekintetében mind a tesztek, mind az összes korcsoport esetében. Az egyéb mutatók (átlagos originalitás, relatív flexibilitás és a revideált átlagos originalitás) különbségei nem jelentősek.
\end{abstract}

Keywords: kreativitás, kreativitás teszetek, felülvizsgálat

Diszciplína: pszichológia 
In the research of creativity - after the upswing in the $60 \mathrm{~s}-80 \mathrm{~s}$ - a revival may currently be observed again on Hungary (see research of Tóth and Király, 2006; Zétényi, 2010; Pléh, 2010; Barkóczi, 2012; Münnich, 2011; Mező F. 2013; Mező K. 2015; Péter-Szarka, Tímár \& Balázs, 2015; Hanák, 2015). This revival may be explained by several reasons: on one hand, the actuality of applied research studying creativity - beyond the fact that this research raised so far unsolved theoretical questions and conflicting viewpoints - derives from such practical demands made explicitly or implicitly by institutions of public education subject to Law CXC (2011) of National Public Education, the National Talent Programme (see resolution of Parliament 126/2008), non-profit organizations (e.g. the network of Talent Point - which comprises more than 1000 organizations - of the Alliance of Organizations for Talent Promotion) and the Human Resources Managements of profitoriented companies.

On the other hand, a higher appreciation of the role of creativity has an invigorating effect on creativity research - see all the social measures and documents which prioritize creativity, competitiveness (e.g. in the programme of lifelong learning) as well as the investment into knowledge and creativity (see: European Union Programme 2020). Each of the above indicated organizations and documents has a vested interest in the study and/or selection of creative individuals and/or the development of creativity in one way or another.

Practical solutions based on research have a significant role in meeting such demands and interests and the basis of such research (contrary to the multi-disciplinarity of the topic) is provided by empirical psychological studies. Any psychological approach to creativity may be taken as a basis, time appears as a latent or explicit factor in each of them although the role of time is less frequently studied directly in creativity research (Mainemelis, 2002). While engrossed in the topic, we were confronted with the surprising experience how very little research has been conducted into the temporality of creativity on Hungary.

The study of Runco (1999) reveals that it is similar in the case of international research: although there may be few more important factors than time in the production of works, there are no overviews or meta-analyses focusing on the role of time in creativity.

In this study we examine the temporal aspects of creativity focuses revision of Hungarian versions of creativity tests because last standardization of these tests had been for more than 20 years.

\section{Background factor of research}

When devising our research plan, creativity tests corresponding to national standards - the Circles test among figural tests appearing in the Hungarian adaptation of TTCT and the Alternative Uses Task among the verbal tests were thought to be reconsidered. As a starting point, the arguments for using the tests were taken into account then we examined the necessity of their reconsideration.

Arguments for using creativity tests standardized in Hungary:

- by applying the tests individually or in groups, we may be able to receive information about children; so an application in schools may be easily carried out even in a busy curriculum;

- the standardization of the creativity tests introduced by Zétényi (1989) is based on a national sample as opposed to Anglo-Saxon data;

- test were proven reliable based on the reliability indicators of test-retest introduced by Zétényi (1989)

- the tests are willingly applied in the pedagogicalpsychological practice (e.g. the János Arany Talent Programme in Hungary)

These arguments speak for the application of the tests but one might also need to realize that they are due to be reconsidered. The necessity of reconsideration of the national creativity tests:

- The descriptions of the tests and guidelines for evaluation were introduced in 1989 - more than 25 years ago (Zétényi, 1989). Their test adaptations introduced in this publication were even earlier published (the national adaptations of the Alternative Uses Task were completed by Barkóczi-Klein in 1968 - more than 45 years ago; The Circles Task by Torrence was published in 1974 more than 40 years ago). The reconsideration of the standards in the test booklet taking the years past into account is long overdue.

- Based on the description by Zétényi (1989) it may be concluded that the majority of participants taking part in standardization were over 18 , i.e. from the adult population.

- Consequently, the current form of the evaluation table of the tests is not adapted to the age characteristics of primary and secondary school students.

- The effect of generational changes of the past 40 years was not followed by creativity tests. The spread of digital networks has brought about new behavioural patterns and those of 
speech and expression, whose certain elements have already appeared in creativity studies as well but are difficult to interpret on the basis of the old (Zétényi, 1989) evaluation.

It may be argued that a continuous, up-to-date modification - dependent on cultural impacts - of the evaluation system of the tests may be difficult to complete but a supervision at least in every ten years - which has not occurred in the case of national tests - would be advisable. Based on all these, we conducted our research: revision of Hungarian versions of the Alternative Uses and Circles creativity tests in cases of elementary and secondary schools students.

\section{Method}

The objective of the study is the revision of $\mathrm{Al}$ ternative Uses Task and Circles Task. This study includes two sub-studies:

1) Revision of Alternative Uses Task and Circles Task with regard to responses within and between peer groups: With respect to responses, we asked questions in relating to the temporal aspects of fluency, originality and flexibility scores whose results confirmed the necessity of reconsideration the indicators of originality and the compilation of evaluation boards with them.

Our hypotheses are:

Hypothesis 1. With regard to fluency an development (an increase in the number of answers) will be observed in the case of both tests with age.
Hypothesis 2. Considering originality, a difference may be observed between the earlier originality of responses and the scores of reconsidered originality.

Hypothesis 3. Considering flexibility, responses will not have an equal distribution among conceptual categories.

2) Revision of Alternative Uses Task and Circles Task with regard to individuals within and between peer groups: A study with respect to individuals was necessary to obtain an answer whether an evaluation alongside different indicators of creativity is needed or a unified indicator may be sufficient. At the same time, we confirmed that the evaluation tables published by Zétényi (1989) are not adjusted to the characteristics of students and they needed to be applied according to age groups at least.

Our hypotheses are:

Hypothesis 4. Significantly strong $\left(\mathrm{r}_{\mathrm{s}}=\right.$ between 0,85 and 0,98$)$ correlations were found between earlier and reconsidered indicators of Alternative Uses Task and Circles Task in all age groups.

Hypothesis 5. There is a significant difference between the creativity test results of age groups (junior, senior and secondary school students) on the basis of the old and reconsidered evaluation tables.

\section{Participants}

The sample of this study was 1363 elementary and secondary school students, whose 35331 responses were recorded and analyzed (Table1).

Table1. Sample. (Source: Authors' editing)

\begin{tabular}{|l|r|r|r|r|r|r|r|r|}
\hline \multirow{2}{*}{ Stimulus } & \multicolumn{2}{|c|}{$\begin{array}{c}\text { Junior grade } \\
(\mathbf{n}=\mathbf{1 4 0} \text { person) }\end{array}$} & \multicolumn{2}{c|}{$\begin{array}{c}\text { Senior grade } \\
\text { (n=563 person) }\end{array}$} & \multicolumn{2}{c|}{$\begin{array}{c}\text { Secondary school } \\
\text { (n=660 person) }\end{array}$} & \multicolumn{2}{|c|}{$\begin{array}{c}\text { Total } \\
\text { (n=1363 person) }\end{array}$} \\
\cline { 2 - 10 } & Responses & $\begin{array}{c}\text { Responses } \\
\text { /person }\end{array}$ & Responses & $\begin{array}{c}\text { Responses } \\
\text { /person }\end{array}$ & Responses & $\begin{array}{c}\text { Responses } \\
\text { /person }\end{array}$ & Responses & $\begin{array}{c}\text { Responses } \\
/ \text { person }\end{array}$ \\
\hline Brick & 290 & 2,07 & 2457 & 4,36 & 3001 & 4,55 & 5748 & 4,22 \\
\hline Key & 186 & 1,33 & 1846 & 3,28 & 2295 & 3,48 & 4327 & 3,17 \\
\hline Pencil & 197 & 1,41 & 2195 & 3,90 & 2712 & 4,11 & 5104 & 3,74 \\
\hline $\begin{array}{l}\text { Total Ver- } \\
\text { bal* }\end{array}$ & 673 & 4,81 & 6498 & 11,54 & 8008 & 12,14 & 15179 & 11,13 \\
\hline Figural** & 1465 & 10,46 & 8555 & 15,20 & 10132 & 15,35 & 20152 & 14,79 \\
\hline $\begin{array}{l}\text { Total Ver- } \\
\text { bal and } \\
\text { Figural }\end{array}$ & 2138 & 15,27 & 15053 & 26,74 & 18140 & 27,48 & 35331 & 25,92 \\
\hline
\end{tabular}

* Stimulus words ('brick', 'key' and 'pencil') of verbal creativity test

** Circles stimulus of Figural creativity test 


\section{Instruments}

In all studies the Alternative Uses Task from the verbal creativity tasks (Barkóczi and Klein, 1968), the Circles Task from the figural tasks (Torrance, 1974) (whose standardized evaluation method was published: Zétényi, 1989) were applied. When selecting tests, we attempted to select ones which could be applied to both verbal and figural creativity and those which are generally applied nowadays in the course of talent studies. The Raven nonverbal intelligence test was applied as a complementary means of study.

Alternative Uses Task

An Alternative Uses Task is a paper- pencil creativity test (working time: $5 \mathrm{~min}$.) based on three stimuli (e.g. a brick, a key, a pencil).

\section{Circles Task}

A Circles Task is a paper- pencil creativity testwhich may be conducted in groups - which includes 35 stimuli (circles) (Working time: there is no information in the booklet published by Zétényi; 5-8-10 min.)

The indicators of creativity examined by the tests:

- Fluency (F): measurement of range of ideas and easiness of expression. It may be measured by the number of assessable responses. A high score provides information on flexibility of thinking.

- Originality $(\mathrm{O})$ : it measures of singularity, originality, novelty and rarity of responses. It is the measurement of frequency of responses. According to Zétényi (10.1989) „This indicator may be the most sensitive one to indicate to what extent the individual's thinking is characterised by divergent productivity."

- Flexibility $(\mathrm{X})$ : it indicates how many different categories the subject has given responses to. A high score indicates that the subject has grasped the response information from many sides. A low score indicates schematic thinking.
- Average originality $(\hat{\mathrm{A} O}=\mathrm{O} / \mathrm{F})$ : this indicator may provide a reference as to how high the scores of originality may be irrespective of the number of responses. A high score indicates that the individual's responses are generally unusual and original (Mező and Mező, 2008).

- Relative flexibility $(\mathrm{RX}=\mathrm{X} / \mathrm{F})$ : the quotient of the fluency and flexibility indicators per item or test. A high score indicates that the individual attempted to approach the task from many sides, communicated many options.

A complementary means of study: the Raven nonverbal intelligence test: The instrument is in a broader sense applied to study average intelligence, in a narrower sense to study cognitive ability. It is a paper- pencil creativity test- which may be conducted in groups. (Mező and Kurucz, 2014).

\section{Procedure}

Participation was not obligatory in this study. The students and their parents were informed about the subject of the study before testing and they were able to make a decision about whether to participate or not. Consequently, our subjects had some kind of internal motivation to participate in this examination, so we did not need to use external motivators (e.g. money, good marks etc.) in order to involve participants.

We met our participants on two different occasions during this examination. In the first session, we tested creative thinking by applying the Alternative Uses Test and Circles Test. On the second occasion participants filled in the Raven SPM test. Every session lasted around 45 minutes, and was held at their school.

\section{Results and conclusions}

The $1^{\text {st }}$ hypothesis was confirmed only in part as a significant difference could only be detected between junior and senior age groups, in the case of secondary age group a stop in development can be detected (Figure 1.). 
Figure1.: changes of the responses/person values of the age groups. (Source: Authors' editing)

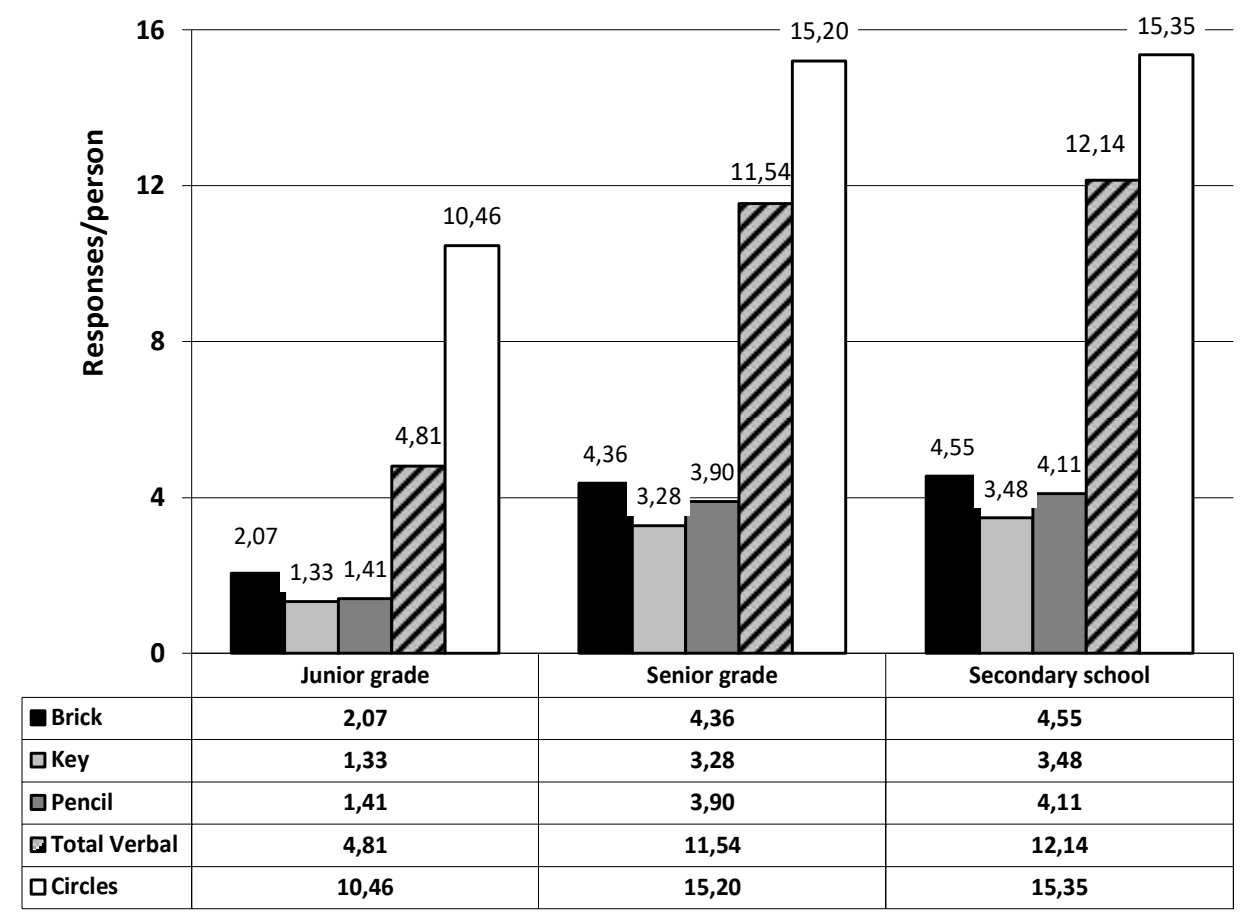

According to Mann-Whitney's U-test, there are significant $(\mathrm{p}<0,05)$ differences between junior and senior grade students' fluency scores ( $\mathrm{U}_{\text {Brick }}=$ 14833; $Z_{\text {Bick }}=-9,174 ; \mathrm{U}_{\mathrm{Key}}=11728,5 ; \mathrm{Z}_{\mathrm{Key}}=$ 7,499; $\mathrm{U}_{\text {Pencil }}=10914 ; Z_{\text {Pencil }}=-7,909 ; \mathrm{U}_{\text {Circles }}=$ $\left.20837 ; Z_{\text {Circles }}=-8,573\right)$, but there is not significant differences between fluency scores of senior grade students and secondary school students.

The $2^{\text {nd }}$ hypothesis was confirmed, considering originality, a difference can be observed between the earlier originality of responses and the scores of reconsidered originality (Table 2). These differences indicate culture-dependency of creativity tests in temporal sense: from the perspective of twenty-five years, the pattern of the frequency of answers in these tests varies considerably. Conclusion: there is a difference between the earlier and reconsidered scores of originality so evaluation tables with new, reconsidered scores of originality must be developed.

Table 2: paired comparison of earlier and revised values of originality. (Source: Authors' editing)

\begin{tabular}{|c|l|r|}
\hline Stimulus & \multicolumn{1}{|c|}{ Subsample } & \multicolumn{1}{|c|}{ Z } \\
\hline \multirow{3}{*}{ Brick } & Junior grade & $-1,165$ \\
& Senior grade & $-3,007^{*}$ \\
& Secondary school & $-3,736^{*}$ \\
& Total & $-4,980^{*}$ \\
\hline \multirow{3}{*}{ Key } & Junior grade & $-6,331^{*}$ \\
& Senior grade & $-7,265^{*}$ \\
& Secondary school & $-3,753^{*}$ \\
& Total & $-9,237^{*}$ \\
\hline \multirow{3}{*}{ Pencil } & Junior grade & $-5,222^{*}$ \\
& Senior grade & $-13,902^{*}$ \\
& Secondary school & $-13,882^{*}$ \\
& Total & $-20,656^{*}$ \\
\hline \multirow{2}{*}{ Circles } & Junior grade & $-9,233^{*}$ \\
& Senior grade & $-13,882^{*}$ \\
& Secondary school & $-19,059^{*}$ \\
& Total & $-24,947^{*}$ \\
\hline
\end{tabular}

$*_{\mathrm{p}} \leq 0,05$ (Paired Wilcoxon's signed-rank test) 
The $3^{\text {rd }}$ hypothesis was confirmed, responses do not have an equal distribution among conceptual categories (Table 3). In the case of all stimuli, irrespectively of age groups, there are categories with higher and lower number of responses.
However, the arrangement of categories has changed when compared to the earlier evaluation table which makes a rearrangement of the order (weightedness) of the categories in evaluation tables necessary.

Table 3: distribution of responses among categories by stimulus and age groups. (Source: Authors' editing)

\begin{tabular}{|c|c|r|r|r|r|}
\hline Stimulus & $\begin{array}{c}\text { Distribution of responses among categories } \\
* *\end{array}$ & Junior grade & Senior grade & $\begin{array}{c}\text { Secondary } \\
\text { school }\end{array}$ & Total sample \\
\hline Brick & Chi-square (df= 15): & $263,062^{*}$ & $2774,750^{*}$ & $3675,482^{*}$ & $6629,578^{*}$ \\
\hline Key & Chi-square (df = 21): & $\begin{array}{c}0,535^{* * *} \\
(\mathrm{df}=13)\end{array}$ & $1917,025^{*}$ & $2580,018^{*}$ & $4380,965^{*}$ \\
\hline Pencil & Chi-square (df =14): & $302,606^{*}$ & $1561,923^{*}$ & $2044,184^{*}$ & $3625,124^{*}$ \\
\hline Circles & Chi-square (df $=29):$ & $2088,008^{*}$ & $6811,800^{*}$ & $8151,088^{*}$ & $15538,791^{*}$ \\
\hline
\end{tabular}

$* \mathrm{p} \leq 0,05$

** Possible number of categories in case of a given stimulus is $\mathrm{df}+1$. For example: in case of 'Brick" stimulus, there are $15+1=16$ categories.

*** $\mathrm{df}=13$ (because junior students did not give evaluable responses in cases of 8 categories)

Table 4. Paired comparison between age groups. (Source: Authors' editing)

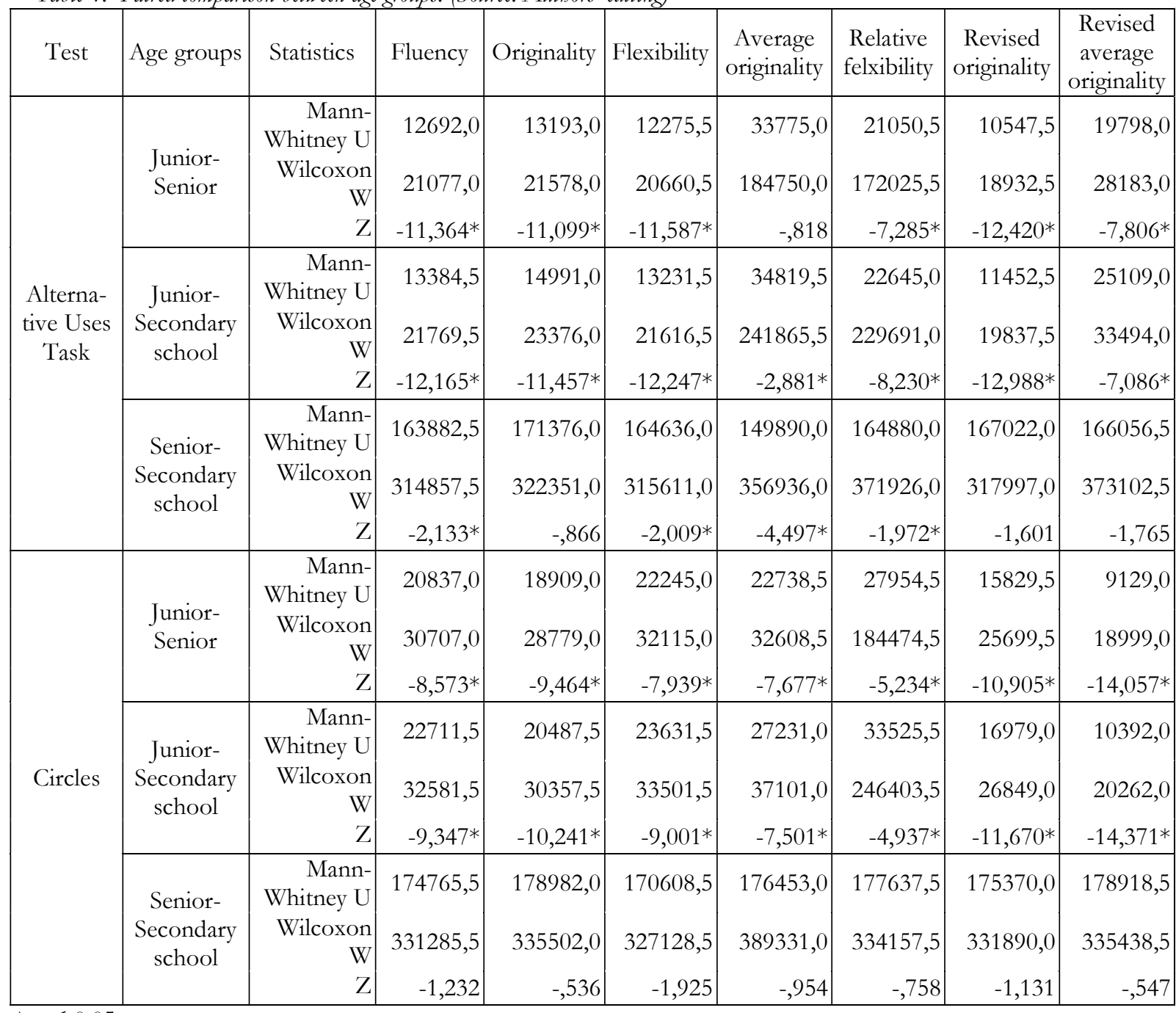

$* \mathrm{p} \leq 0,05$ 
The $4^{\text {th }}$ hypothesis was confirmed in part. Significant correlations were found between earlier fluency, originality and flexibility indicators of creativity in all age groups $\left(r_{s}=0,85-0,98 ; p<0,05\right)$. However, in the case of other indicators (average originality, relative flexibility and reconsidered average originality) the correlations are weak or moderate negative. From the inverse proportionality, it may be inferred that with the increase in the number of responses thinking becomes more and more schematic.

However, the appearance of lower flexibility alongside high fluency may refer to elaboration in a given category. All these may question the justification of the use of one indicator of creativity.

The $5^{\text {th }}$ hypothesis was confirmed: There is a significant $(\mathrm{p} \leq 0,05)$ difference in all indicators between scores of junior, senior and secondary school students (Table 4). The difference is more significant between the junior and senior age group and less significant between the senior and secondary age group.

All these draws our attention to the fact that a unified scoring system of creativity tests - compiled mostly on the basis of the responses by adults may not be necessarily suitable to evaluate the creativity of younger students that is why evaluation tables according to age groups must be made. The revision of Hungarian creativity tests is timely.

\section{REFERENCES}

Barkóczi, I. (2012). A pozitív pszichológia és a kreativitás kapcsolata. Magyar Pszichológiai Szemle, 67(1). 173-181.

Barkóczi, I., \& Klein, S. (1968). Gondolatok az alkotóképességről és vizsgálatának problémáiról. Magyar Pszichológiai Szemle, 25. 508-515.

Hanák, Zsuzsanna (2015): Állandóság és változás az iskolaérettség megítélésében. Képrés és gyakorlat: Training and Practice 13. (1-2.) 221-230.

Mainemelis, C. (2002). Time and Timelessness: Creativity in (and out of) the Temporal Dimension. Creativity Research Journal, 14 (2). 227-238.
Mező, F. (2013). Measurement and estimation of originality. In: Angyalosi, G. - Münnich, Á. Pusztai, G. (Eds.), Interdisciplinary Research in Humanities (.457-472). Nitra: Constantine the Philosopher University in Nitra, Faculty of Central European Studies.

Mező, F. \& Kurucz, Gy. (2014). Az APMIntelligencia teszttel kapcsolatos vizsgálati tapasztalatok a Debreceni Egyetem tehetséggondozó programjában 2002-2008 között. Budapest: Géniusz-Műhely.

Mező, K. (2015). Kreativitás és élménypedagógia. Kocka Kör Tehetséggondozó Kulturális Egesület, Debrecen.

Mező K. (2017). A kreativitás idóbeli aspektusai. Doktori disszertáció, Debrecen.

Münnich, Á. (Szerk.). A kereativitás többszempontú vizsgálata. Debrecen: Didakt Kiadó.

Péter-Szarka, Sz., Tímár, T., Balázs, K. (2015). Iskolai Kreatív Klíma Kérdőív. Alkalmazott Pszichológia, 15 (2). 107-132.

Pléh, Cs. (2010). Kreativitás, tehetség és gyakorlás: hangsúlyváltások a kutatásban. Magyar Pszichológiai Szemle, 65. (2). 199-220.

Runco, M. A. (1999). Time. In: M. A. Runco, S. Pritzker (Eds.), Encyclopedia of creativity. 659-663. CA: Academic. (Vol. 2).

Torrance, E. P. (1974). The Torrance Tests of Creative Thinking-Norms-Technical Manual Research Edition$V$ erbal Tests, Forms $A$ and B- Figural Tests, Forms $A$ and $B$. Princeton, NJ: Personnel Press.

Tóth, L., \& Király, Z. (2006). Új módszer a kreativitás megállapítására: A Tóth-féle Kreativitás Becslő Skála (TKBS). Magyar Pedagógia, 106(4), 287-311.

Zétényi, T. (1989). A kreativitás-tes ztek tesztkönyve III. Budapest: Munkalélektani Koordináló Tanács,

Zétényi, T. (2010). A kreativitás pszichometriája és a gondolkodás. Magyar Pszichológiai Szemle, 65 (2), 233-242. 